\title{
新合繊布の凹凸感とすべり抵抗感
}

\author{
京都府立大学人間環境学部 泉加代子 \\ 京都工芸織維大学繊維学部 秋山隆一 \\ 広島大学教育学部 木下瑞穂

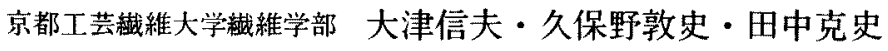

\section{Surface Roughness and Slipping Resistance of Shingosen Fabrics}

\author{
Kayoko Izumi ${ }^{* 1}$, Ryuichi Akiyama ${ }^{* 2}$, Mizuho Kinoshita ${ }^{* 3}$, \\ Nobuo Ohtsu*2, Atsushi Kubono ${ }^{* 2}$ and Katsufumi Tanaka ${ }^{* 2}$
}

\footnotetext{
${ }^{* 1}$ Faculty of Human Environment, Kyoto Prefectural University, Kyoto, 606-8522 Japan

${ }^{* 2}$ Faculty of Textile Science, Kyoto Institute of Technology, Kyoto, 606-8585 Japan

${ }^{* 3}$ Faculty of Education, Hiroshima University, Higashihiroshima, Hiroshima, 739-8524 Japan
}

\begin{abstract}
We take up the surface roughness and slipping resistance as the tactile parameter to explore the surface properties of Shingosen fabrics. Thirty kinds of Singosen fabrics to be classified into four groups: Peach Skin (PS), Rayon Dry (RD), New Silky (NS) and New Worsted(NW) were chosen. Three sensory tests: Surface Rubbing test(SR), Folded Rubbing test(FR) and Folded Slipping test (FS) were selected, and twenty-two students assessed the surface roughness and slipping resistance. Relationships between the results of three sensory test and four Shingosen groups were obtained as follows; 1) PS is not rough and has large slipping resistance with the low weight. 2) RD is largely rough and has small slipping resistance with the low weight. 3) NS has small slipping resistance with the low weight. 4) NW is not smooth and has large slipping resistance with the low weight. Yet it slips with applied force. Based on the assess of SR, FR and FS, the fabrics were classified into four clusters. Cluster 1 was coincide with PS and Cluster 2 was coincide with RD. But, Cluster 3 and 4 were composed several groups of Shingosen. Furthermore, by Quantification theory II, it was possible to discriminate among the four groups of Shingosen based on three sensory test of the surface roughness and slipping resistance.
\end{abstract}

(Received 3 March, 1999 ; Accepted 19 July, 1999)

\section{1. 緒 言}

新合载は微妙な手触り感をもっており，その手触り 感から薄起毛調(PS), レーヨンドライ調(RD), ニューシ ルキー調(NS)およびニュー梳毛調(NW)で表現されてい る.これらは, 新合緎の属性を表す総合的な風合い用語
として用いられている。

専門家は，布の風合いを判断する時，布表面を手指で 押したり，摖ったり，軽く引っ張ったり，曲げたりする ことにより布の物理的な性質を調べている，その中で， 押す，擦るという触運動は，専門家だけでなく一般消費 者も行う最も基本的な布の手触り判断法であると考えら 
れる。

布を押す，擦るという触運動により，皮屑に接触刺激 が与え放れると、真皮に分布している触圧党の受容器が 刺激される。刺激俚神経瀻維を伝わって大脳度質の体性 感觉領域に達し、さまざまな情報に基ついいて全体像を把 握するパターン認識が行われる[1].

ポリエステルを素材とする新合䋐布は, 撚りや織構造 に起因するマクロな凹凸に加えて、単系断面のシャープ なエッジによるミクロな凹凸や極細瀻維のループによる ミクロな凸凸があり，皮虑刺激に对する凹凸バターンを 多様に変化させてある。このことから，凹凸感が新合紸 の表面特性の特徵を捉える基本的な触感の一つであると 考えられる。一方，表面の凹凸が小さいサンドぺーパー を擦ると，凹凸感は感しないが，すべりに对する抵抗感 を感しることを経験する。これらのことから，新合械布 の基本的な触感は凹凸感に，すべりに对する抵抗感が加 わるのではないかと推測される。

新合織布の力学特性および客観的評価法による風合い の特街に関しては，小山・丹羽・川端[2]や松平[3]によ って報告されている。我々もこれまでに，55種類の新合 伡布竧,判定者 8 名による手触り評価でPS, RD, NS, NW $の 4$ 種類のグループに分け，各クループの触感の特徵を 摩擦と圧縮の力学的計測から検討した[4,5]. しかし, 新 合载布の触感を主観的に評価し分析した研究は見あたら ない、そこで，本研究では，新合䋐布の表面四凸より誘 起される凹凸感とすべり抵抗感を手触り評便のパラメー ターとして取り上げ、その評価と新合繊の属性を表す薄 起毛調, ニューシルキー調, レーヨンドライ調, ニュー 梳毛調の総合風合いとの関係をクロス表分析, クラス夕 分析. 数量化理諭II類による分析から検討する.

\section{2. 万法}

\section{1 弪料}

試料は「最新衣料素材(瀻維学会編) [6]」に収集されて いる布サンプルからポリエステル素材の新合樴布 30 種類 を選定したこれんらの試料は，まず 2 名の專門家がPS, RD， NS.NWの 4 つの風合いダループの代表サンプルを選び, その代表サンブルに近似した手触りでグループ分けする ように8名の判定者(教員・学生)によって分類されてい る[4]. 試料の大きさは $170 \times 150 \mathrm{~mm}$ で，その詳細を表 $1 に$ 示す。

布の表面と断面は, 光学顕徽鏡で観察した。

\section{2 評俩方法}

布の凹凸感とすべり抵抗感の評洒は，室温27度、湿度 65\%の環境で次の3つの手法で行った。判定者は22名(女 子学生10名, 男子学生12名)であり, 先の試料を 4 つの風
Table 1 Details of sample

\begin{tabular}{|c|c|c|c|c|c|}
\hline \multirow[t]{2}{*}{$\begin{array}{c}\text { Sample } \\
\#\end{array}$} & \multirow[t]{2}{*}{$\begin{array}{l}\text { Weave } \\
\text { Type }\end{array}$} & \multicolumn{2}{|c|}{$\begin{array}{c}\text { Yarn density } \\
{\left[\mathrm{cm}^{-1}\right]}\end{array}$} & \multicolumn{2}{|c|}{$\begin{array}{c}\text { Yarn count } \\
{[\mathrm{D} / \mathrm{f}]}\end{array}$} \\
\hline & & warp & weft & warp & weft \\
\hline 1 & Plain & 70 & 40 & $75 / 24$ & $75 / 24$ \\
\hline 2 & Plain & 76 & 45 & $50 / 24$ & $75 / 36$ \\
\hline 3 & Backed Satin & 101 & 39 & $100 / 72$ & $100 / 72$ \\
\hline 4 & De chine & 76 & 43 & $60 / 36$ & $75 / 36$ \\
\hline 5 & Plain & 36 & 33 & $100 / 84$ & $100 / 84$ \\
\hline 6 & Plain & 57 & 30 & $140 / 72$ & $140 / 72$ \\
\hline 9 & Ottoman & 68 & 32 & $80 / 36$ & $80 / 36$ \\
\hline 10 & Crepe de chine & 61 & 33 & $80 / 36$ & $80 / 36$ \\
\hline 12 & De chine & 81 & 35 & $50 / 22$ & $150 / 96$ \\
\hline 13 & Voil & 92 & 74 & $150 / 54$ & $150 / 96$ \\
\hline 25 & Plain & 66 & 37 & $105 / 37$ & $60 / 48$ \\
\hline 27 & Plain & 57 & 57 & $75 / 36$ & $*$ \\
\hline 28 & Backed Satin & 107 & 55 & $80 / 84$ & $80 / 84$ \\
\hline 29 & Twill & 66 & 34 & $110 / 168$ & $110 / 168$ \\
\hline 30 & Plain & 51 & 40 & $90 / 150$ & $90 / 156$ \\
\hline 31 & Crepe de chine & 73 & 49 & $60 / 36$ & $75 / 66$ \\
\hline 32 & Plain & 65 & 45 & $110 / 180$ & $100 / 48$ \\
\hline 33 & Twill & 74 & 42 & $70 / 32$ & $75 / 200$ \\
\hline 34 & Twill & 94 & 46 & $50 / 18$ & $50 / 18$ \\
\hline 36 & $1 / 2$ Twill & 63 & 31 & $75 / 36$ & $150 / 1500$ \\
\hline 37 & Twill & 61 & 38 & $30 / 12$ & $75 / 20$ \\
\hline 40 & Twill georgette & 92 & 35 & $90 / 36$ & $90 / 36$ \\
\hline 41 & Plain & 46 & 32 & $105 / 30$ & $100 / 96$ \\
\hline 44 & Venetian & 78 & 38 & $105 / 96$ & $167 / 48$ \\
\hline 46 & Gabardine & 51 & 28 & $170 / 66$ & $150 / 48$ \\
\hline 47 & $3 / 2$ Twill & 57 & 28 & $210 / 60$ & $210 / 60$ \\
\hline 49 & Twill & 65 & 39 & $160 / 84$ & $160 / 84$ \\
\hline 52 & Amunzen & 81 & 50 & $140 / 60$ & $140 / 60$ \\
\hline 54 & Cashimere & 70 & 37 & $160 / 66$ & $15 / 96$ \\
\hline 55 & Venetian & 89 & 34 & $110 / 36$ & $220 / 72$ \\
\hline
\end{tabular}

合いグループに分類する官能評価の判定者は含まれてい ない。

\section{(1)SR (Surface Rubbing)法}

判定者に利き手の人差し指または中指で布表面を摖ら せた，触運動方向は，評価に長い時間を要すると判定能 力の低下がみられたので，一番基本的なたて糸方向のみ を採択した。評価に際しては，あらかしめ判定者に全試 料を擦らせ, 試料の四凸感の上限と下限を把捏させた。 新合械布を対象としているので，四凸感の籍囲が限られ ていること, 判定者が非尃門家であることを考虑して, 
0出来るだけ判定方法を単純化し，以下の方法で手触り 感の回答を得た。

1)試料の凹凸感の有無を，1(ある)または0(ない)で 回答を求めた。

2)凹凸感が 1 の回答を得た試料については，凹凸感の 大小について，1(大きい)または 0(小さい)で回答を求 めた。

3) 四凸感が0の回答を得た試料については，すべりに 对する抵抗感の有無を，1(ある)または 0 (ない)で回答 を求めた。

布表面を手指で擦る際，触感に对する押圧力と速度の 影響を調べるために，押圧力を 3 段階，速度を 2 段階変 化させたすなわち，押压力は，“レベル 1 ：手首を台に かいて擦る゙ルレベル $2 ：$ 肘を台に置き肘を支点にして摖 る゙レレベ 3：腕を台にのせないで肩を支点にして擦る゙ の3段階で,レベル2の押圧力は約20gwtに相当する。触 速度は，“レベル1：ゆっくりと擦る”“レベル2：速く 擦る゙の2 段階を採用し,レベル1の速度は約 $1 \mathrm{~mm} / \mathrm{secに}$ 相当する。

凹凸感とすべり抵抗感についてはそれぞれの有無によ ク４通りの組み合かせがある。しかし，本研究では凹凸 感加あると評価された場合には，すべり抵抗感の有無を

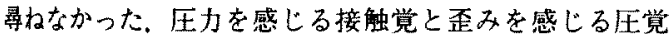
を比べると，感党の応答時間には違いがあり，接触党の 媔庥性は圧賞に比べると速いことが知られている[7]. 皮 成は布表面の凹凸による压力分布を優先的に感じると判 断したからである。

\section{(2)FR(Folded Rubbing)法}

SR法と同しくたて糸方向を採択し，たて方向に2つ折 クした布を，手首を台に置いて手指で擦った時の，布一 右間のすべり抵抗感を尋极た。（すべる）または 1 (すへ らないで回答してもらった。

\section{(3)FS(Folded Slipping)法}

低荷重下での布一布間のすべり抵抗を観測するために 图1のような傾斜法を用いた。前述のSR法, FR法が主観 語洒であるので，FS法も客観的手法ですべり角度を測定 してそのまま用いることは行わなかった，台紙を水平か ら除々に傾斜させ，折り重ねた布の上部がすべり出す角

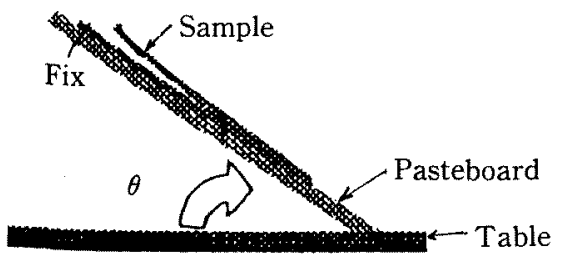

Fig. 1 Schematic diagram for Folded Slipping Test (FS)
度を判定者が目測し， 0 (45度以下ですべり出す場合)， 1 (45 90度ですべり出す場合)，2 (90度以上ですべり出 す場合)として回答させた。

\section{3 分析方法}

SR法での評洒を 4 カテゴリー, FR法を 2 カテゴリー, FS法を 3 カテゴリーに分類して, PS, RD, NS, NWの 4 つの総合風合いグループとのクロス表分析を行い，各グ ループの凹凸感とすべり抵抗感の特徴やグループ間の差 異を明らかにした，また，クラス夕分析を行って凹凸感 とすべり抵抗感の評価から試料を類型化し，4グルーブ の属性との関係を検討した。さらに 4 グループの判別に 凹凸感とすべり抵抗感が有効であるかどうかを検討する ために数量化理論II 類による分析を行った。

\section{3. 結果および考察}

\section{1 凹凸感およびすべリ抵抗感の評価と4グループとの 関係}

すべての評価の単純集計結果を表 2 に示す。記号はは 試料番号, Handは新合䋐布の総合風合いである薄起毛調 (PS), レーヨンドライ調(RD), ニューシルキー調(NS) およびニュー梳毛調 $(N W)$ を表す。第 3 列のjudgeは判定 者 8 名の判定結果である.すなわち，試料＃12はRDと判 定した人が 5 名, NSと判定した人が 3 名であることを表 している，第 2 列と第 3 列は寸でに報告した結果である [4].

SR法で評価した凹凸感およびすべり抵抗感の結果を第 4 列から第 7 列に示した. $S R_{11}$ は手首支点でゆっくりし た速度で擦った場合を表している。“凹凸感，すべり抵抗 感がない”をカテゴリー1，“凹凸感はないがすべり抵抗 感がある”をカテゴリーII，“四凸感が小さい”をカテゴ リーIII，“凹凸感が大きい”をカテゴリーIVに分類した。 第 4 列 第 12 列までの数字は，それぞれ判定者 22 名によ る評価結果を度数で表している。

折り返した布を手指で擦ったFR法の結果を第 8 列およ び第 9 列に示した，折り返した布を手指で摖る際，抵抗

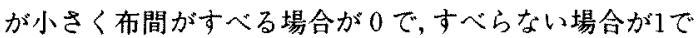
ある.

第10列～第12列は，FS法による傾斜時のすべり抵抗の 結果である，第12列は垂直にしても試料がすべり落ちな いことを表し、試料３33は22名の観測結果が同じである ことを示している.

SR法では，布表面を手指で擦る際の触感に对する押圧

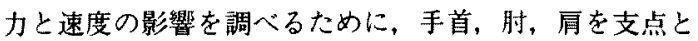
した 3 レべルの押圧力に対して，それぞれ 2 レベルの触 速度で布表面を擦る 6 通りの手触り評洒を行なった。を の評価ごとにI〜Nの4カテゴリーとPS, RD, NS, NWの 
Table 2 Statistical result of sensory test

\begin{tabular}{|c|c|c|c|c|c|c|c|c|c|c|c|}
\hline \multirow[b]{2}{*}{$\#$} & \multirow[b]{2}{*}{ Hand } & \multirow[b]{2}{*}{ Judges } & \multicolumn{4}{|c|}{$S R_{11}$} & \multicolumn{2}{|c|}{ FR } & \multicolumn{3}{|c|}{ FS } \\
\hline & & & I & II & III & IV & 0 & 1 & 0 & 1 & 2 \\
\hline 1 & & & 0 & 3 & 6 & 13 & $\begin{array}{ll}5 & 1\end{array}$ & 17 & 2 & 20 & 0 \\
\hline 2 & & & 8 & 7 & 3 & 4 & 14 & 8 & 21 & 1 & 0 \\
\hline 3 & & & 0 & 1 & 3 & 18 & 101 & 12 & 19 & 3 & 0 \\
\hline 4 & & & 6 & 4 & 9 & 3 & 13 & 9 & 22 & 0 & 0 \\
\hline 5 & $\mathrm{NS} / \mathrm{PS}$ & & 10 & 5 & 5 & 2 & 15 & 7 & 1 & 21 & 0 \\
\hline 6 & NW/NS & & 3 & 1 & 12 & 6 & 121 & 10 & 18 & 4 & 0 \\
\hline 9 & & & 10 & 6 & 4 & 2 & 121 & 10 & 19 & 3 & 0 \\
\hline 10 & & & 1 & 0 & 9 & 12 & 14 & 8 & 10 & 12 & 0 \\
\hline 12 & $\mathrm{RD} /$ & & 1 & 3 & 14 & 4 & 14 & 8 & 22 & 0 & 0 \\
\hline 13 & & & 0 & 0 & 5 & 17 & 18 & 4 & 21 & 1 & 0 \\
\hline 25 & & & 13 & 7 & 2 & 0 & 31 & 19 & 0 & 1 & 21 \\
\hline 27 & $\mathrm{PS} / 1$ & & 9 & 7 & 5 & 1 & 121 & 10 & 1 & 19 & 2 \\
\hline 28 & NS/PS & & 5 & 7 & 8 & 2 & 51 & 17 & 13 & 9 & 0 \\
\hline 29 & & & 11 & 11 & 0 & 0 & 101 & 12 & 0 & 4 & 18 \\
\hline 30 & $\mathrm{PS} / \mathrm{NS}$ & & 9 & 6 & 6 & 1 & 121 & 10 & 0 & 14 & 8 \\
\hline 31 & NS & & 10 & 7 & 5 & 0 & 13 & 9 & 18 & 4 & 0 \\
\hline 32 & & & 11 & 11 & 0 & 0 & 101 & 12 & 7 & 15 & 0 \\
\hline 33 & $\mathrm{PS} / \mathrm{NW}$ & & 5 & 14 & 1 & 2 & 22 & 20 & 0 & 0 & 22 \\
\hline 34 & PS & & 15 & 7 & 0 & 0 & 81 & 14 & 0 & 10 & 12 \\
\hline 36 & PS & 8,0 & 11 & 9 & 1 & 1 & 51 & 17 & 0 & 11 & 11 \\
\hline 37 & & 8,0 & 10 & 12 & 0 & 0 & 41 & 18 & 0 & 4 & 18 \\
\hline 40 & & & 1 & 1 & 10 & 10 & 16 & 6 & 18 & 4 & 0 \\
\hline 41 & & & 0 & 0 & 7 & 15 & 91 & 13 & 6 & 12 & 4 \\
\hline 44 & NW & & 9 & 10 & 3 & 0 & 18 & 4 & 13 & 9 & 0 \\
\hline 46 & $\mathrm{NW} / \mathrm{RD}$ & 4,4 & 0 & 3 & 7 & 12 & 15 & 7 & 4 & 18 & 0 \\
\hline 47 & $\mathrm{NW}$ & 8,0 & 2 & 7 & 9 & 4 & 15 & 7 & 1 & 21 & 0 \\
\hline 49 & NW/PS & 5,3 & 12 & 5 & 5 & 0 & 19 & 3 & 19 & 3 & 0 \\
\hline 52 & & & 0 & 0 & 1 & 21 & 13 & 9 & 15 & 7 & 0 \\
\hline 54 & NW & 7,1 & 6 & 8 & 5 & 3 & 17 & 5 & 16 & 6 & 0 \\
\hline 55 & NW & & 3 & 6 & 7 & 6 & 18 & 4 & 2 & 20 & 0 \\
\hline
\end{tabular}

PS: Peach Skin, RD: Rayon Dry, NS: New Silky, NW: New Worsted

$4 つ の$ 風合いダループとのクロス表分析を行い， $x^{2}$ 値を もとに独立性の検定を行った結果，いずれの場合もグル 一プによって評洒に違いが認められ，0.01\%水準で有意 差がみられた．变数間の関連の強さの指標となるクラマ 一のv保数を表 3 に示す．記号 $\mathrm{i}$ は手首、时および骨を 支点とする触璉動に对応し，触速度 $\mathrm{j}$ の数字はレベル1,2 に对応している，押圧力が大きく，速度が速くなると， 4 カテゴリーと 4 グループの関道の強さが弱方傾向が 認められるが、いすれれの場合もクラマーの、係数 $(\sqrt{\mathrm{cr}})$ は 高い値を示している。
Table 3 Cramer's $\mathrm{V}$ by terms of Surface Rubbing Test (SR)

\begin{tabular}{cccc}
\hline & \multicolumn{3}{c}{$\mathrm{i}$} \\
\cline { 2 - 4 } $\mathrm{j}$ & 1 & 2 & 3 \\
\hline 1 & 0.405 & 0.401 & 0.386 \\
2 & 0.388 & 0.380 & 0.359 \\
\hline
\end{tabular}

i: applied force, is speed of finger movement

赤松・貞本は、研磨紙の粗さの判別には押圧力と指を 動かす速度が影響を及はすすと報告しているが[8]，評価を 徙属变数，押圧力 (3レベル) と速度 (2レベル)を要因とす る二元配置分散分析を行うと，押圧力の違いによる有意 差は，どのグループからも認められなかった，本研究で は，人間の感覚を重視し，指の押圧力と摖る速度の計則 を行なっていないため個人差があったのではないかと思 われる。しかし，速度の違いについては，PSクループで $1 \%$ 水準, NWグループで $5 \%$ 水準で有意差か認められ, この 2 クループの試料は速く擦ると評価が变わることか 明らかとなった。

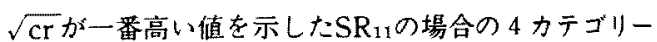
と 4 クループとのクロス表分析の結果を図 2 に示す. 30 種類の試料の中には，2つのグループに判定がなされた 試料が 9 種類あり，それを両方のグループに入れると， 39種類となるが，39種類で分析すると，1 つのクルーブ に判定された21種類の試料の評洒の重みが半減する。そ こで，1つのグループに判定された試料を二重にカウン トして，計60種類として分析した，カテゴリーIとIIは よく似た傾向を示し、どちらもPSグループの試料が約半

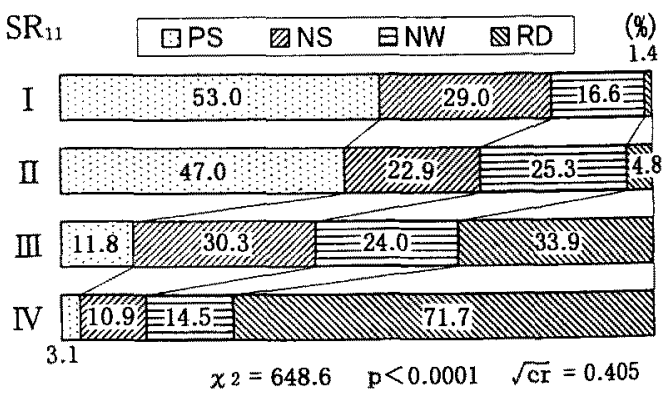

Fig. 2 Relationship between four categories of Surface Rubbing Test (SR) and four groups of Shingosen fabrics

Category I: no roughness/no slipping resistance, Category II: no roughness/slipping resistance, Category III: roughness/low level, Category V: roughness/high level 
数を占かており、RDグループの試料をカテゴリーIと評 偭したケースは1.4\%,カテゴリーII 評洒したケースは 4.8\%と非常に少ない。それに対してカテゴリー Vと評価 れれた武料はRDグループが粎 7 割を占め, PSグループは $3.1 \%$ に過ぎない,SR法の凹凸感の有無および凹凸感の大 きさの大小の評価のみでPSとRDグルーブの特衟を明確に とらえることはできる。しかし、NSおよびNWグループ の武料はI－同カテゴリーに分散している.NSグループ は四凸感もすへり抵抗感もない，あるいは小さい四凸感 があると栖価された試料が若干多く、NWグループは凹凸 感はないがすべり抵抗感がある，あるいは小きい四感 があると評洒された試料が若干多い傾向が認められるが， 明政ではない。

表 2 をると，同一試料でもすぐり抵抗感の有無の評 価加分かれている場合が多い。このことから，手指一布 間のすへり抵抗感は，本研究の判定者のように布の触感 に日常関心がはとんどない者にとっては捉えに々い感賞 ではないかと思われる。

次に，布を折り返して摖り，布一布閐のすべり抵抗感 を評洒した，ての結果と4タループとのクロス表分析を

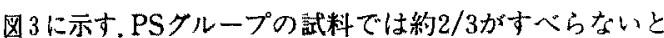

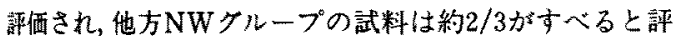
洒されている，しかし，NSとRDグループの試料につい ては，すべるの評価が若干多いが明瞭な゙傾向は認められ ない，指が湿っていると摩撩係数が堌加することが報告 されており[9],手指の皮盧の乾燥度の個人差に起因する 手指一布間の摩擦力と, 布一布間の摩摖力の大小関保が 評佰に影響を及はしているからではないかと考えられる。

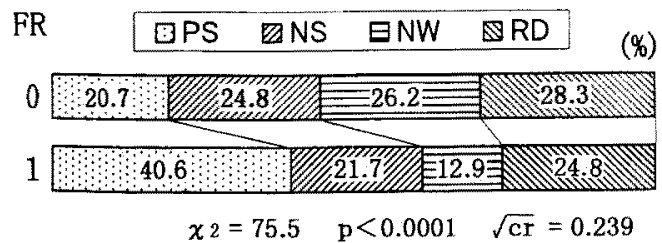

Fig. 3 Relationship between two categories of Folded Rubbing Test (FR) and four groups of Shingosen fabrics

Category 0: slip, Category 1: not slip

そこで，布を擦らないで布一布間すべり抵抗を評価す る方法としてFS法を用いた，通常の摩摖武験では接触端 子を安定に移動するために，布表面に $10 \mathrm{gwt} / \mathrm{cm}^{2}$ 程度の 押在力を加えなけ耴ばならないが、このFS法では布の自 重による低荷重下での布一布間静止摩擦力を，表面形態 に大きな影謷を与之ないで観測できる利点がある、FS法
FS $\triangle P S$ QNS ENW QRD

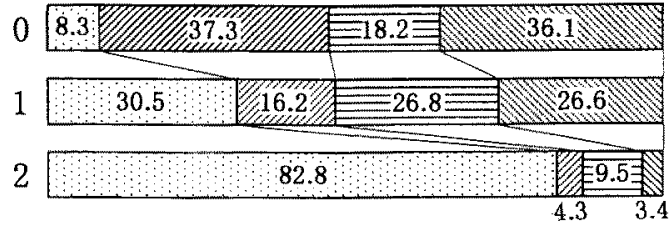

$x_{2}=492.5 \quad \mathrm{p}<0.0001 \quad \sqrt{\mathrm{cr}}=0.432$

Fig. 4 Relationship between three categories of Folded Slipping Test (FS) and four groups of Shingosen fabrics

Category $0: 0<\theta<45^{\circ}$, Category $1: 45^{\circ} \leqq \theta<90^{\circ}$, Category 2: $90^{\circ} \leqq \theta, \quad \theta=$ slipping angle

での評洒と4ダループとのクロス表分析の結果を図4に 示す.グループ間に差異が明確に認められ、 $\sqrt{\mathrm{cr}}$ 值も0.432 の高い值が得られた，45度以下の傾斜ですバり出すのは NSとRDグループの試料が多く，低荷重下での布一布間 子バり抵抗が小さい，す心゙り抵抗が極めて大きく，垂直 にしてもすべらない試料の8割以上がPSグループである。 NWグループはその中間に位笛している.

SR法でカテゴリ一I戈よU゙Iの度数が大きい、すない ち凹凸感がないと評偭された武料をみると，SR法でのす ベり抵抗感の有無からグループ間の特徵を明らがはる ことは難しい，しかし，FS法を合わせて採用することに より，凹凸感がないと評価された試料の中で，低荷重下 での市べり抵抗が極めて大きい試料はPSグループに属し， すべり抵抗が小さいと評価された試料はNSグループに属 することが明確となる。また逆に，FS法で低荷重下での すへり抵抗が小さい試料をみると,NSグループだけでな く凹凸感の大きいRDグループの試料属しており,FS法 だけでは新合臷布の微妙な表面の特街を捉えられないこ とがわかる、すなわち、これらの評価法を合わせて行う ことにより，4グループの風合いの特徴が把握できると 思われる。

\section{2 クラスタ分析による試料の類型化}

SR11法,FR法, FS法の謤価を变数として行ったクラス 夕分析(Ward法)から得られたデンドロクラムを図 5 に示 す.4タルーブと対応するように，破線の值置でデンド ロクフムを分割し，4つのクラスタを得た。

\#25一２90試料からなるクラス夕1は，凹感がなく， 低荷重下での布一布間すべり抵抗が極めて大きいと評価 されたPSグループのクラスタである.このクラス夕に含 まれるPSケループの試料は，表面を観察すると分割型断 面形状の鋭いエッシををち，数多いループで覆われたミ クロな凹凸形状をしているので，すべり抵抗が数めて大 


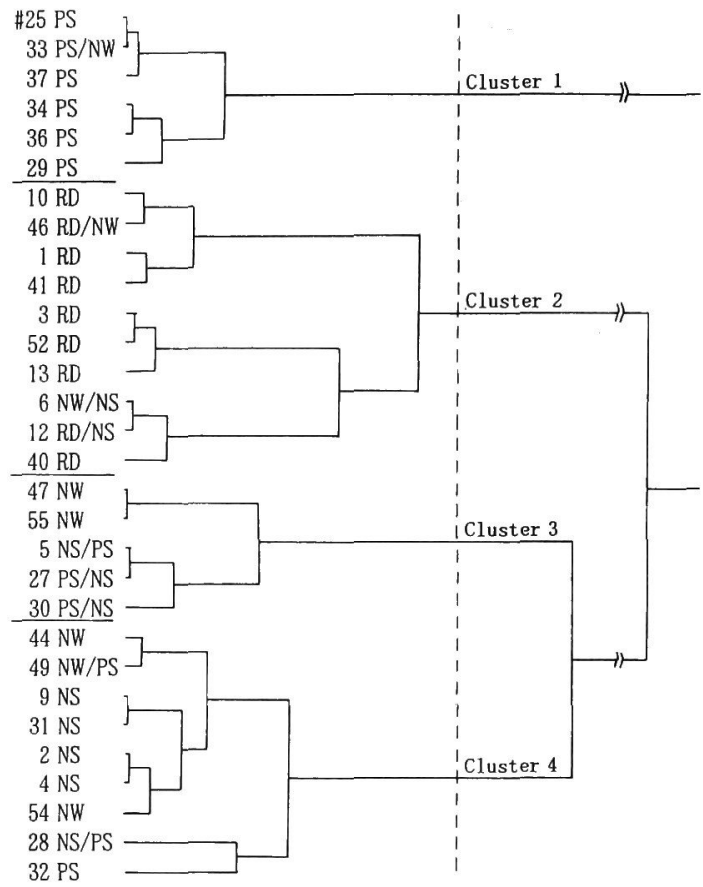

Fig. 5 Result of Cluster analysis
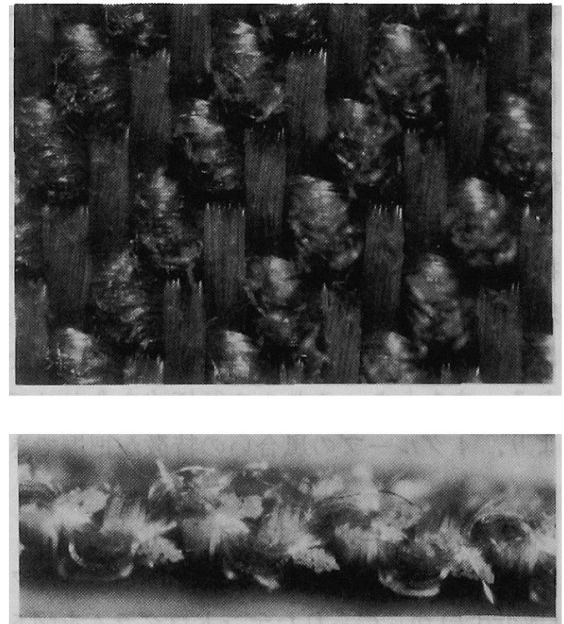

Fig. 6 Surface and section photograph of \#34(PS)

きいと考えられる(困6)。

\#10〜 \#40の試料からなるクラスタ 2 は, 四凸感が大 きく，低荷重下での布一布間すべり抵抗が小〜中程度の RDグループと,凹凸感はあるがそれ程大きな凹凸感では なく, 低荷重下での布一布間すべり抵抗が小さいRDクル 一プが結合したクラスタであり,試料\#6(NW/NS) を除
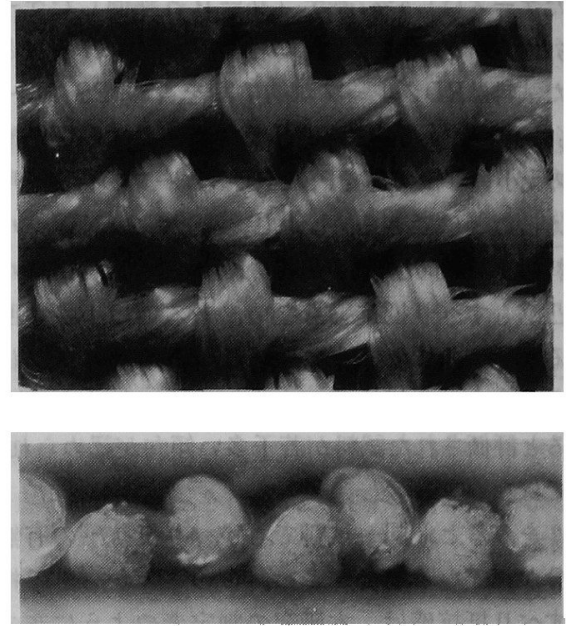

Fig. 7 Surface and section photograph of \#13(RD)
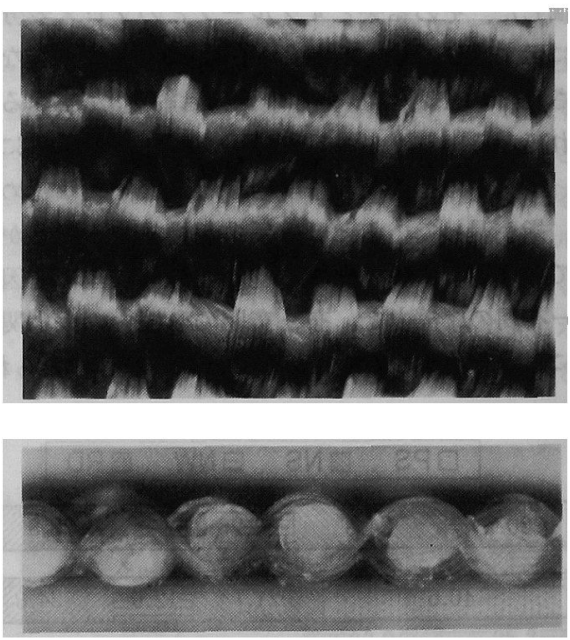

Fig. 8 Surface and section photograph of \#12(RD/NS)

くとすべてRDグループの試料から構成されている.凹凸 感が大きいと評価されたRDグループの試料\#13の写真を 見ると(図7)，強撚系によるマクロな四あるいは単系断 面がシャープエッジによるミクロな凹凸が見られ，不規 則な凹凸構造をもっている.これらRDクループの試料は， 撚りによる明瞭な凹凸があるので低荷重下では接触面積 が減り，すべり抵抗があまり大きくならないと推測され る.一方，凹凸感が小さいと評価された試料\#12は，凹 凸の振幅は大きいが規則性のある周期構造となっており (困8)，NSの触感があると判定されている. 
\#47〜 \#30の試料からなるクラスタ 3 は，凹凸感が小 さいと評洒されたNWグループと凹凸感がないと評価され たPS/NSおよびPSクループの試料が結合したクラスタで あり，低荷重下での布一布間すべり抵抗は中程度と評洒 されている.

\#44〜３2の試料からなるクラスタ 4 は，凹凸感がな いと評価されたNSおよびNWのグループと, 凹凸感が小 さいと評洒されたNS/PSおよびPSクループの試料が結合 したクラスタで，低荷重下での布一布間すべり抵抗が小 さいと評価された試料から構成されている。試料井 32 は PSクループと判定されているが，丸味を帯びた単系から なりルループが少ない凹凸形状であるので，クラスタ 1 に属するPSグループとは簧なるすべり挙動を示したと思 われる.

クラスタ分析で武料の類型化を試みた結果，クラスタ 1 はPSクループ, クラスタ 2 はRDグループと合致した。 クラスタ 3 と 4 に関しては，RDを除く複数のグループか ら構成されているが，4グループに分類する際に，2つ のタループに判定が分かれた試料があるように，新合裁 布の手能りは非常に微妙であり,PS,NS, NW, RDの 4 グ ループに分類することはかなり難しく，2つのグループ に属する布があることが新合樴布の特色の 1 つであると 考えてよいのではないかと思われる。

また, クラスタによって織組織, 織密度, 系番手数に 特徵がみられるか検討したが、これらの構造要因との对 応は認められなかった，人間はこれらの構造要因から生 しる個々の凹凸形状を触感として感じとっているのでは なく,総合的に把握しているのではないかと推測される。

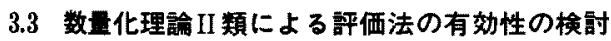

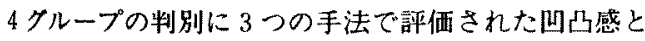
すべク抵抗感が有効であるかどうかを検討するために, $\mathrm{PS}, \mathrm{NS}, \mathrm{NW}, \mathrm{RD}$ の クループを外的基準, $\mathrm{SR}_{11}$ 法, FR 法, FS法による評価を説明変数と寸る数量化理論 II 類に よる分析を行った，2つのグループに判定されている 9 試料を除いて21種類の試料で分析した結果， 3 つの根が 得られ，相関比 $(\eta)=0.705$ のかなり高い精度が得られた。

図9は、4クループごとにそのクループに属する試料 の得点の平均值をプロットしたものである.第 1 根(横軸) では, PSクループが右に, RD, NS, NWグループが左 にきており，第 1 根はPSグループを他の 3 グループから 区別する根といえる。第 2 根((1)の縦軸)では，RDグル ープが上に, NSとNWグループが下にきており，第 2 根 はRDクループをNSとNWクループから区別する根といえ る. 第3根((2)の綐軸)は, NWグループが下に, NSグル 一プが上にきており，NWグループとNSグループを区別 する根である。
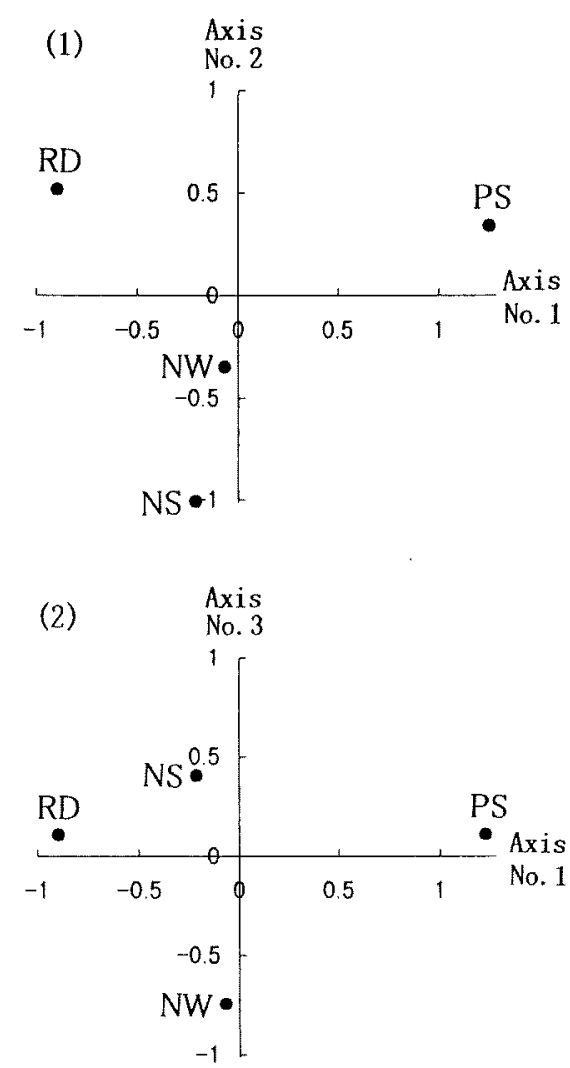

Fig. 9 Result of Quantification theory II analysis using $\mathrm{SR}_{11}, F R$ and $F S$ tests for Shingosen groups. Plots of sample mean score:

(1) axis No.1 vs. axis No.2, (2) axis No.1 vs. axis No.3.

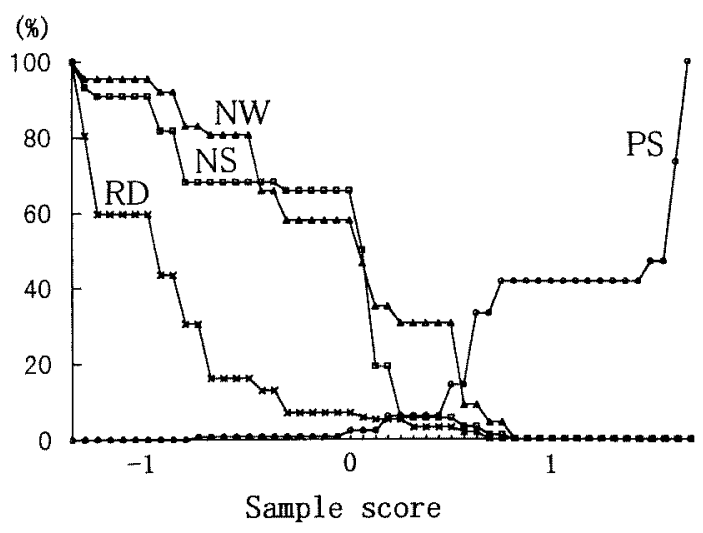

Fig.10 Accumulated percentage of frequency distribution by sample score for Shingosen groups (axis No.1) 
Table 4 Category score, range and partial correlation by explanatory variables

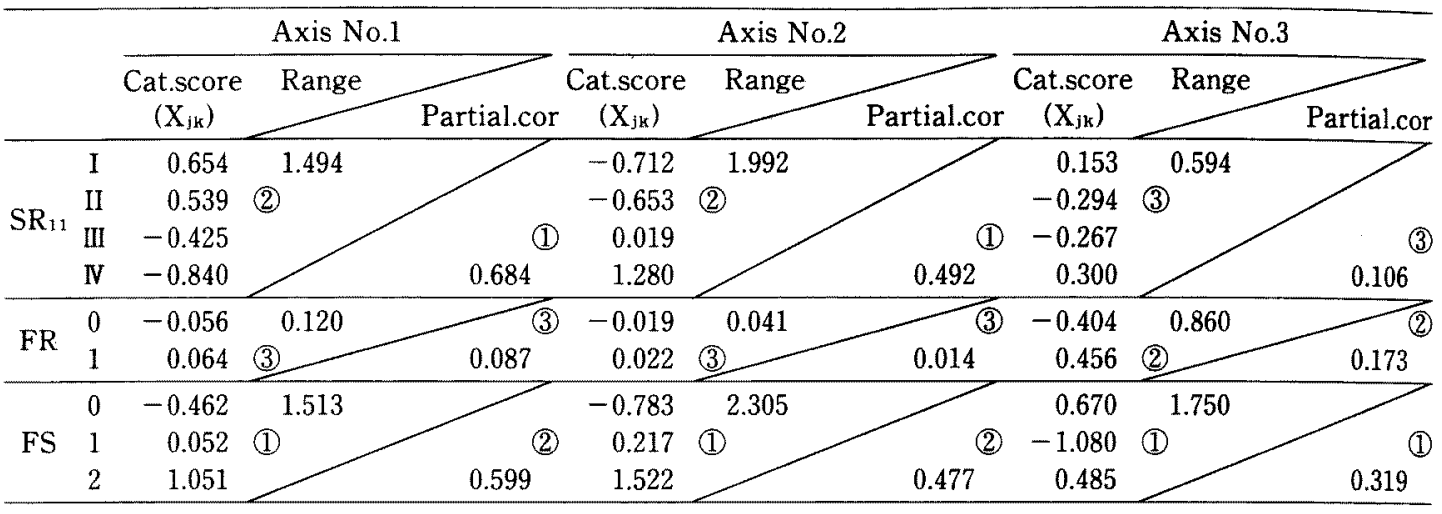

図10は，第 1 根に対する試料得点のグループ別度数分 布を累積百分率として示している。第 1 根は, PSとRDグ ループを約 $95 \%$ ，PSとNSグループを約 $94 \%$, PSとNW グループを約 $86 \%$ の的中率で判別を予測することができ るといえる.同様に，第 2 根および第 3 根に対する武料 得点のグループ別度数分布を累積百分率のグフから， 第 2 根はRDとNSグループを約 $82 \%$, RDとNWグルーブ の判別を約 $72 \%$ の的中慗で，第 3 根はNWとNSグループ の判別を約 $67 \%$ の的中率で予測できることが求められた.

表 4 に, 各説明姿数のカデゴリーに与えられた数值(ウ エイト)と各説明変数のレンシと偏相関係数を示した. 䙌 中の(1)(2)(3)の数字は值の大きさの順位である。第 1 根, 第 2 根ともにSR 11 法とFS法の寄与が大きく,それぞれPS と他の 3 タループ, RDグープとNSおよひNWグループ を判別するのに有効な変数であるといえる．また，第 3 根にはFS法の次にFR法が寄与している。このことから， NWグループとNSグループとの判別にFR法も貢献してい ることがわかる.

\section{4. 結 論}

新合樴布の表面特性を捉える触感として，凹凸感とす ヘりに対する抵抗感をとりあげ, SR(Surface Rubbing) 法, FR(Folded Rubbing)法, FS(Folded Slipping)法の 3つの手法を用いて凹凸感およびすべり抵抗感を評洒し， 新合截布の属性を表す薄起毛調(PS),レーヨンドライ調 $(\mathrm{RD})$, ニューシルキ一調 (NS), ニュー梳毛調 (NW) との 関係を検討した， 3 手法の評偭値とPS, RD,NS, NWの 4 グループとのクロス表分析から各グルーブの特幑をまと めると，以下のようになる。

1)PSグループは凹凸感がない. 低荷重下での布一布間 すべり抵抗は極めて大きい，折り返した布のすべり抵抗 感も大きい。
2) RDグループは円凸感が大きい。低荷重下での布一布 間すべり抵抗は小さい。

3)NSグループは低荷重下での布一布間すべり抵抗は小 है.

4) NWグループは四凸感もすべり抵抗感もない試料は少 ない，低荷重下での布一布間方べり抵抗は大きいか，布 を折り返した状態で手指で押圧力を加えるとすべり抵抗 感は小さくなる.

また， 3 手法の評価值を変数とするクラス夕分析を行 って試料の類型化を試み 4 つのクラスタを得た、クラス 夕3と 4 に関してはRDを除く複数のグループから構成さ れているが, クラスタ 1 はPS, クラスタ 2 の試料はRDク ループと合致することを確かめた.

さらに，4グループの判別に対する 3 評価法の有効性 を検討するために，数量化理諭II類による分析を行った 結果, 相関比 0.705 のかなり高い予測精度が得られ, PSと 他の 3 グループは約86 95\%の高い的中率で判別が可能 であり、判別が難しいNSとNWグループは約67\%の的中 率であることが明らかとなった。

これらのことから，凹凸感とすべり抵抗感は新合臷の 表面特性の特致を捉えるのに有効な触感であることが確 かめられた.すべりに对する抵抗感の評価法に関しては， さらに検討を重ねる余地が残されていると考えている。

なお，新合縺布の凹凸形状の機器計測および手触り感 との対応づけについては次報で報告する予定である。

\section{文献}

1. T. Ooyama, S. Imai and T. Wake, "Shinpen Kankaku Chikaku Shinrigaku Handbook”, Seishinsyobou, p.1178(1994).

2. Y. Koyama, M. Niwa and S. Kawabata, Proceeding of 20th Text. Res. Symp., p136(1991). 
3. M. Matsudaira, J. Text. Inst., 85[2], 158(1994).

4. R. Akiyama, H. Xia, M. Kinoshita, F. Okamoto, K. Tanaka and T. matsuo, Sen'i Kikai Gakkaishi, 48, 153(1995).

5. M. Kinoshita, S. Noda, R. Akiyama and T. Matsuo, Sen'i Kikai Gakkaishi, 50, 187 (1997).

6. "Recent Materials of Apparel Use (man-made part), 2nd ed.", (Sen'i Gakkai), Bunka
Syuppankyoku (1993).

7. K. Yamaba, "Sensa Katsuyou Gizyutu", (Kogyou Tyou sakai Hensyubu), Kogyou Tyousakai, p297 (1984)

8. M. Akamatsu and Y. Sadamoto, Japanese J. Ergonomics, 25, 183(1989).

9. M. A. Srinivasan, J. M. Whithouse and R. H. Lamotte, J. Neurophysiology, 63, 1323 (1990). 